\title{
Urban Land Use Pattern and Road Network Characteristics Using GIS in Al Salt City, Jordan
}

\author{
Deya Qtiashat ${ }^{1}$, Zeyad Makhmreh ${ }^{1}$, Hala Abu Taleb ${ }^{2} \&$ Ahmed Khlaifat $^{1}$ \\ ${ }^{1}$ Department of Geography, Faculty of Arts, University of Jordan, Amman, Jordan \\ ${ }^{2}$ Department of English Studies, Faculty of Foreign Languages, University of Jordan, Amman, Jordan \\ Correspondence: Zeyad Makhmreh, Department of Geography, Faculty of Arts, University of Jordan, Amman, \\ Jordan. E-mail z.makhamreh@ju.edu.jo
}

Received: February 1, 2018

doi:10.5539/mas.v12n4p128

\author{
Accepted: March 14, 2018 \\ Online Published: March 30, 2018 \\ URL: https://doi.org/10.5539/mas.v12n4p128
}

\begin{abstract}
The aim of this study is to analyze the land use pattern and roads network in relation to the population density and distribution. The GIS analysis tools was used to investigate and describe the characteristics of land use pattern. method by utilizing the methods of surveying and spatial statistical analysis, and studying the areas' topography; which includes the optimal land use and assessment through aerial photography that determines the future urban development besides determining the role played by the roads network within the study area. The study show that the residential use is dominant in the study area with $77.19 \%$. The study also showed that the urban growth was random and accompanied by the increase demand on the use of land for residential purpose. The study recommended paying more attention to the agricultural activities in Al Salt city and establishing a commercial organization that attracts visitors from the capital city of Amman who would like to get out of the city busy life but still stay near the capital city of Amman.
\end{abstract}

Keywords: land use, road network, GIS, Jordan

\section{Introduction}

The patterns of land use effects the transportation planning that includes the transportation structure, roads network, car parking and airports (Abu Madena,2008). Roads network receives special interest by countries as the primary infrastructure element that contributes to the economic development and providing security and strength (Al Tarzy,2003). Land use development patterns (also known as urban form, built environment, community design, spatial development, and urban geography) refer to human use of the earth's surface, which including the location, type and design of infrastructure such as roads and buildings characteristics. Land use patterns have diverse economic, social and environmental impacts: some require less impervious surface (buildings and pavement, also called sealed soil) and so preserve more open space (gardens, farmland and natural habitat), and some are more accessible and so reduce transportation costs to businesses and consumers. (Arabiyat,2012). Urban land use patterns are increasingly recognized as significant contributors to energy consumption. However, few studies have quantified the impacts of urban land use patterns on energy consumption (Al Sa'di,2002). Also land use affects the environment, public health, economic growth, the distribution of wealth, social outcomes and the attractiveness of cities and towns to population, beside that the land use practices have major consequences on climate change mitigation (Ministry of Municipal Affairs,2005).

Transportation infrastructure is an important human activity which is related closely to the place, and this can be shown in the importance of transportation system to the population activities. Roads have to be made in order to connect different places together to accomplish the concept of movement (Land Transport Regularity Commission,2016). There is often a high level of interaction between the transportation activities and the planning decisions of the land use. For instance, the patterns of land use effects the access to different places and destinations, consequently effecting travel roads and intensity (Ministry of Public Works and Housing,2016). Roads network is a part of the transportation system, and it's the kind of land use that increases the demand on transportation, and vice versa, transportation can play a role in distributing the land use, which makes the relationship between them a reciprocal one (Ghnaim,1999).

Transportation plays a big role in land use planning in order to ensure an easy access to all individuals and 
materials to their destination, besides the linkage of economic services to the transport system and infrastructure such as bus stations, gas stations and car parking. Therefore, it is important to reconsider the land use planning and analyze alternative plans to overcome this obstacle. Al Salt city suffered from poor roads network and infrastructure which resulted in traffic jams and restricts the easy access between different locations, which is consider the most important goal of the transportation system. In general, the trips took longer time and more effort the use of land use patterns shifted and the land use changed from agricultural to residential and commercial, and the direct effect in the transportation system inside the city. (Shehab and Alladin,1990)

The main objective of this study is to analyze the impact of land use and the road network on the population density in Al-salt City. The secondary goals are to get familiar with the roads network condition in Al Salt city and its main features using geographical information systems. Also to investigate the relationship between the land use pattern and the population distributions in the study area.

\section{Literature Review}

Land use can be seen as the visual dimension of the study area resulting from using the land by any human activity such as residential, commercial or industrial...etc. A network of spatial relations is produced by the interaction between these activities, this represent the known flows of economic and human workers, money and goods (Shehab and Alladin,1990). Land use studies are considered one of the most important surveys carried out by planners before commencing to the planning phase. They include a thorough limitation for the types of land use in the area that is planned, this kind of studies is basic for planning, and the outcome of the previous or later planning is actually based on land uses distribution pattern, this means deciding the types of land use that located in different city parts (Al Khaldi,2005). Land use type and roads network is part of the transportation system and vice versa, the means of transportation can play a role in designating the use of the land (Shehab and Alladin,1990). The cities roads network and high ways are the main constructional element in the urban areas, thus occupy big part of it, establishing a connection with the other city places, and together they produce the final image of the city. Streets have many shapes and forms and they are a reflection of the cities economical, historical and topographical situation, that have something to do with the city size and the land ownership and its regional role (Ali,2001).

The neighboring land must be taken into consideration when planning for roads, besides the type of land use classification system. Roads have many types such as highways, internal streets, linking roads and local roads. Besides considering roads as part of the strategic plan, we must show interest in public transportation and commercial transportation movement when preparing the strategic plans for roads and land use pattern (Al Kanani, and Abdel,2007). Land uses represent a number of use patterns depending on different economic, social and demographical elements, in addition to the historical evolution in the area through different periods and land uses in any city is a reflection of the population needs, and employment types. Therefore, the land use patterns in any city is different from any way that can be suggested for other city in planning phase to have a number of population (Ghnaim,2004). Al jabery presents the most land use factors that have modest individual impacts, typically affecting just a low percent of total travel, they are cumulative and synergistic. Integrated Smart Growth programs that result in community design similar to what developed prior to 1950 and can reduce vehicle ownership and travel 20-40\%, and significantly increase walking, cycling and public transit, with even larger impacts if integrated with other policy changes such as public transit service improvements and existing more efficient transport pricing (Al jabery,2010) Asadi studied the relationship between land changes in the northern part of south Iran to estimate the direct impact of expanding the roads network and changing the agricultural land, and assessing their impact on the west Iran network (Asdi,2015). The study showed that 3\% of the agricultural land changed to other types of uses and other kind of infrastructure the main changes to the agricultural roads took place near the main roads in contrast to areas far from the main roads. The changes in the agricultural land were measured using satellite images analysis. The results showed that the agricultural land was mainly shifted to non- agricultural use, which resulted in a dramatic reduction between the year 1990 and the year 2010.

(Al Awayshah,2010) aimed to discover and analyses the population changes and its effect on the land uses in $\mathrm{Al}$ Salt urban city from 1979 till 2010. He shows the land uses evolution pattern in the city, the main results of this study there was a random land use, land expansion and rapid population growth. This resulted in overlap between the existing uses of land. The main recommendations are to redirecting the urban growth towards the east side of the city, and use of the empty areas. (Ghnaim,1999) analyze the impact of the commercial land use distribution inside the Greater Amman Municipality on the traffic accidents inside the city. Ghnaim clarified the relationship between the location of the traffic dangerous and the characteristics of commercial land use, the dominant commercial land use in the city takes a liner shape and spreads on the both sides of the main roads 
(Ghnaim,2004). Sarker studied the roads network characteristics in Kitsch Bihar area in India with the aiming to investigate the current conditions of the roads network. Accordingly, he found out that the area suffers from poor road networks connections which affects the flow dynamics of both people and goods (Sarker,2013). Aduory presented a simulation system for the city and the population planning taking into considerations land use pattern, the roads network map and the land topography. It founded a roads network on three levels that corresponds to the road gradation, the land designation is established on the base of logarithm, and the local and international standards were designed to ensure flexibility and adjustment to the city locations. He predicts the suitable locations for the academic analyses and presented some models for the population density and distribution. The main measures used to find the road path are the starting point, the sector length, the path direction and the end point (Aduory,2010).

\section{Methodology}

\subsection{Study Area}

Al Salt city is about $28 \mathrm{Km}$ northwest of Amman city, located between longitude $\left(\mathbf{3 5}^{\circ} \mathbf{4 3}^{\prime} \mathbf{3 0}^{\prime \prime}\right)$ east and latitude $\left.\mathbf{( 3 2}^{\circ} \mathbf{0 2} \mathbf{3 0}^{\prime \prime}\right)$ north as shown in figure 1. It belongs to middle Mountain regions about $900 \mathrm{~m}$ above sea level, and it considered the administrative center of the Al Balqa governorate. The size of the city is 48 square Kilometer, with a rate of about $61 \%$ of the area of the Greater Salt Municipality, and the area of organization is $35.496 \mathrm{~km} 2$ and $73.95 \%$ of the city area, the population number is around 99938 inhabitants for the year 2015, which represent a $21.2 \%$ from Al Balqa governorate total population number of 447,220 thousand. (Greater Al Salt Municipality,2016)

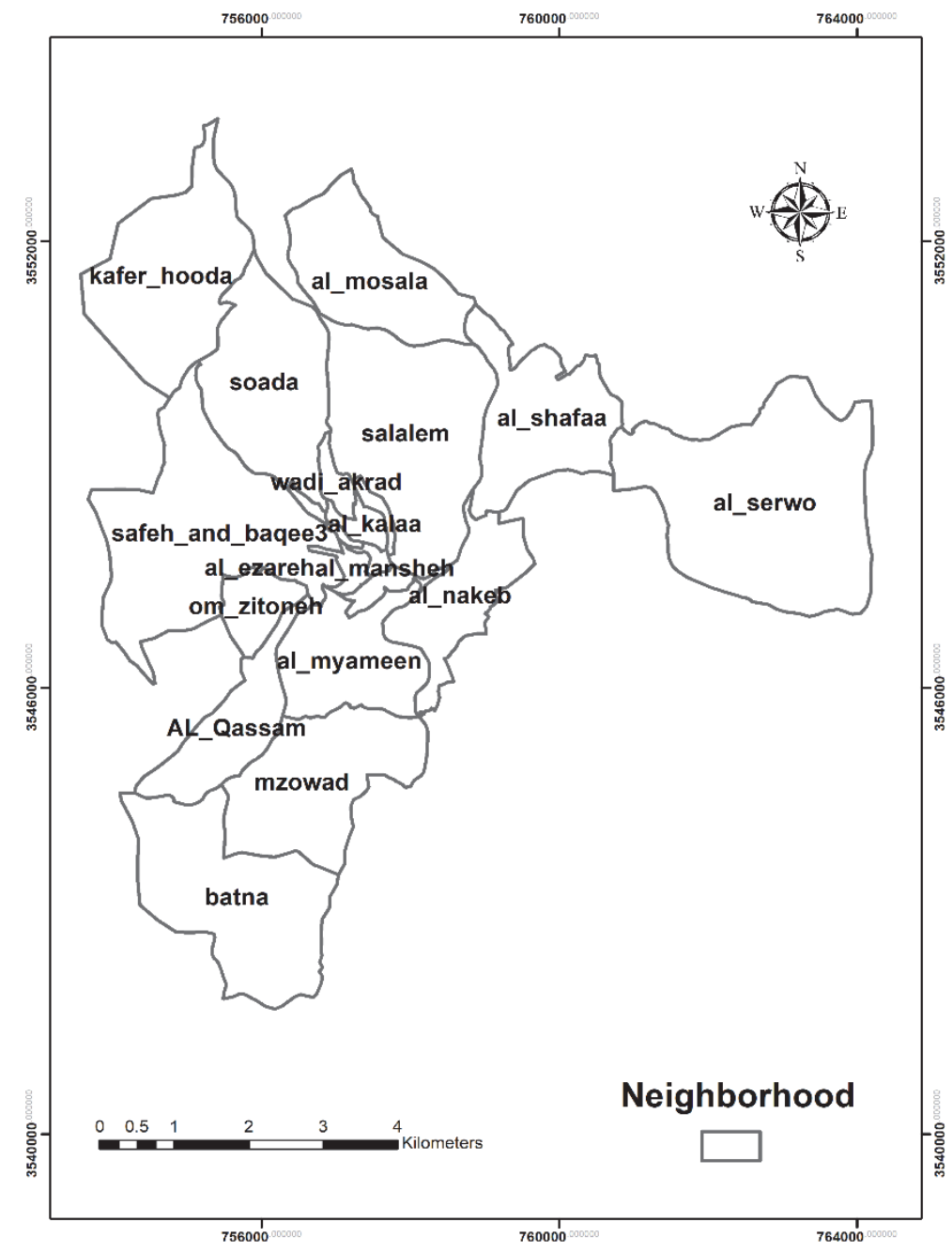

Figure 1. The study area

The climate characterizes with a Mediterranean climate type, where the rainfall starts from late October to end of 
April, and the summer characterized by dry hot conditions. The soil types are very fertile which support the various natural land cover types. The terrain varies from open plains to hills that aren't very steep to high mountains and very steep canyons (Greater Al Salt Municipality,2016)

Al Salt city was established in 1887, and considered the main Ottomans architecture example in Jordan. Al Salt is a unique example of the architectural prosperity to a city that was the center for the Governor 200 years ago (Greater Al Salt Municipality,2016). The city is well known with its breathtaking scenery and its agricultural potentials besides its historic link with Jerusalem and Nablus cities in Palestine before 1967. Al Salt was a regional capital city in the Ottomans Empire as the main civilized area on the east bank of Jordan River. The city itself is built on three main hills; Al Salalem, Al Jad'a and Al Qala'a hills where the city center is located were the three hills meet and there you can find the government institutions and committees, and there is also the center of commercial and cultural activities, public service institutions and markets

\subsection{Spatial Statistical Analysis}

The Data of land use types and road network was collected from the Jordanian Ministry of Works and the municipality of Greater Salt. The spatial analysis facilities that available in the geographic information system was used to analyze the land use distribution and road network characteristics. The aerial photo and satellite images and land have been used to map and analyze the existing land use types using the on-line digitizing methods with high accuracy. GIS spatial models has been used to predict the future urban development direction of the city, and its effect on the transportation network and population growth. The classification scheme was based on the Administration of Urban Renewal and the office of Public Roads, this scheme based on the following characteristics: the building, the total floors size for buildings and the size of the ground floor

Statistical analysis of the road network was based on the following steps:

A- Technique the density of the roads network in relation to the city size:

The density of the roads network in relation to the size is equal the total summation of the roads network length to the city size multiplied by 100 (Al Tarzy,2003) as given in equation (1).

$$
\begin{aligned}
& \mathrm{D}=\left(\sum \mathrm{L} / \mathrm{S}\right) * 100 \% \\
& \mathrm{D}=\text { the density of the roads network } \\
& \sum \mathrm{L}=\text { summation of the total roads length } \\
& \mathrm{S}=\text { city area (square Kilometer) }
\end{aligned}
$$

B- Measuring the density of the roads network in relation to population size.

Measuring the density of the roads network in relation to population is considered the best measurement method, that the population is the most important variable and influence the viability of the roads network, and provide the accessibility for the economic activity.

The density of the roads network is equal the sum of roads length in relation to the population multiplied by 10 thousand as given in equation (2).

$$
\begin{aligned}
& \mathrm{D}=\left(\sum \mathrm{L} / \mathrm{P}\right) * 10000 \\
& \mathrm{D}=\text { the density of the roads network } \\
& \sum \mathrm{L}=\text { summation of the total roads length } \\
& \mathrm{P}=\text { population }
\end{aligned}
$$

C- The density of roads in relation to vehicles number:

The density of roads in relation to vehicles number is the sum of roads length to the number of cars multiplied by a thousand as given in equation (2) (Al Tarzy,2003)

$$
\begin{gathered}
\mathrm{D}=\left(\sum \mathrm{L} / \mathrm{V}\right) * 1000 \\
\mathrm{D}=\text { the density of the roads network to vehicles number } \\
\sum \mathrm{L}=\text { total sum of roads length } \\
\mathrm{V}=\text { Number of vehicles }
\end{gathered}
$$

D- The mean of people number per vehicle can be calculated using equation 4 (Al Tarzy,2003)

$$
\mathrm{M}=\mathrm{P} / \mathrm{VN}
$$




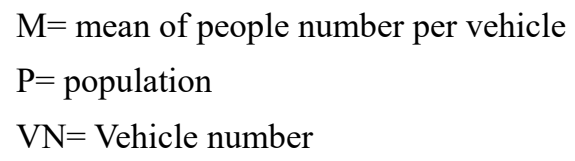

Analysis of the roads distribution pattern was carried out using the Neighborhood Link Method. This method is the closest to the important measurements and methods of geographers, because it provides accurate measurement of the relationship of phenomenon to other phenomena, as a means to measure the extent of concentration or dispersion of geographical features, and this measure is based on a continuous quantitative criterion to determine the spatial distribution of the road network. (Tofic,2015)

Table 1 shows the quantitative significance of each value of the neighborhood link. The values of the neighborhood link ranges from (0-2.15) where each value has a significant quantitative significance sign that shows the spatial distribution pattern. The zero value mean the concentration is reaching the peak value, and as the value increase means more space and dispersion, and the value of 2.15 means highest spacing and spreading conditions.

Table 1. Quantitative significance of each value of the neighborhood link values

\begin{tabular}{|c|c|c|c|}
\hline Distribu & tion pattern & Quantitative significance & $\begin{array}{c}\text { Value of } \\
\text { neighborhood link }\end{array}$ \\
\hline \begin{tabular}{lr|r} 
& $\bullet:$ \\
$\because$ & $\because$
\end{tabular} & $\begin{array}{c}\text { Clustered } \\
R=0\end{array}$ & Assembled in one place & $\mathrm{R}=0$ \\
\hline$\because \because \because$ & & $\begin{array}{l}\text { The closer they came to zero they were gathered } \\
\text { The closer you are to } 0.5 \text { the pattern is close - } \\
\text { The closer one is to the pattern the more randomly - }\end{array}$ & $1>\mathrm{R}>0$ \\
\hline$\because \because$ & Random & $\begin{array}{l}\text { The random pattern is also considered harmonic because the } \\
\text { actual distance is close to the theory }\end{array}$ & $\mathrm{R}=1$ \\
\hline $\begin{array}{l}\because \\
\therefore \\
\because \cdots \\
\therefore\end{array}$ & $\underset{\mathrm{R}=\mathbf{2 . 1 5}}{\downarrow}$ & $\begin{array}{l}\text { The closer the one was to the style, the closer to random. The } \\
\text { closer the value of } 2.1 \text { the pattern was (regular) }\end{array}$ & $2.15>\mathrm{R}>1$ \\
\hline
\end{tabular}

The geographic information systems (GIS) software was used to carry out the statistical analysis parameters such as the neighborhood link method etc. This method allows to understand the spatial distribution pattern of the road network in the study area by measuring the real distance between the geographical location of each station and the geographical location of the nearest station.

The neighborhood correlation coefficient is calculated by applying the mathematical form as shown in equation 5. This allow to calculate the distance between all stations, by divide the calculated rate on the expected rate of the total distances between stations as given in equation (5)

$$
R=2 D x\left(\frac{N}{A}\right)^{2}
$$

where

$\mathrm{R}=$ Value of neighborhood link

$\mathrm{D}=$ Real distance between road network stations 
$\mathrm{N}=$ Number of road network stations

$\mathrm{A}=$ area of study area

\section{Result and Discussion}

\subsection{Streets Characteristics}

The analysis show that the roads in Al Salt looks like a spider web with a central knot that represent the city center, which is a starting point for these roads directed to many directions were the roads come closer and more complicated when it reaches the middle, and grew apart and have branches when you move away from the city center. Studying the street length is one of the important elements of the road network it investigates the spatial relation of the roads networks and its characteristics and analyze it in relation to space, it can give a clear picture about the network and its contribution in the area development. Al Salt city has a group of asphalt, sub and main roads that represent $4 \%$ of the roads in the country. Table 2 shows the length and types of roads in Al Salt in 2015 .

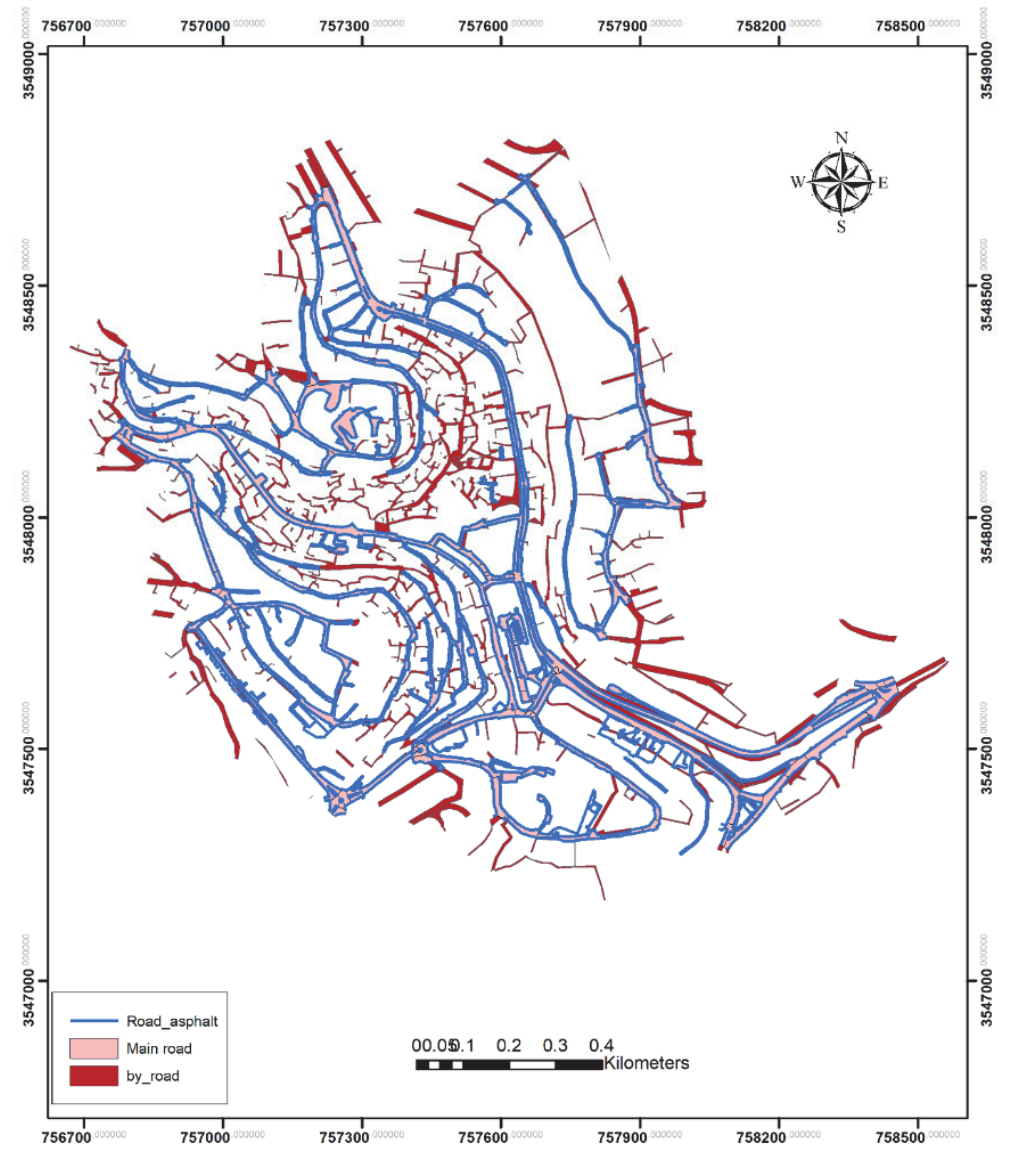

Figure 2. Represents the streets in study area

Table 2. The length and types of roads network in Al Salt city in 2015.

\begin{tabular}{lll}
\hline Type of road & Length $(\mathrm{Km})$ & Percent $(\%)$ \\
\hline Main road & 174.51 & 28.1 \\
\hline By road & 327.80 & 52.8 \\
\hline Asphalt & 118.59 & 19.1 \\
\hline Total & 620.9 & 100 \\
\hline
\end{tabular}

Table (2) shown the roads in the study area was classified according to Road Classification Law at the Ministry 
of Public Work and Housing for the year 1986 and its amendments which classify the roads as the following types:

1. Main road: the road wider than $8 \mathrm{~m}$.

2. By road: the road wider than $6 \mathrm{~m}$.

3. Asphalt road: the road wider than $3 \mathrm{~m}$.

After the application of the proximity test on the road network stations in Salt city, the prevalence of the dispersed pattern was revealed. The neighborhood link analysis shows that the actual mean distance between the nodes is (79.8922) $\mathrm{m}$ which was more than the average expected distance of 63.4932 , this resulting in the nearest neighbor recording a value of (1.25828), this pattern indicates the divergence and regularity in the distribution of population or road nodes in the study area.

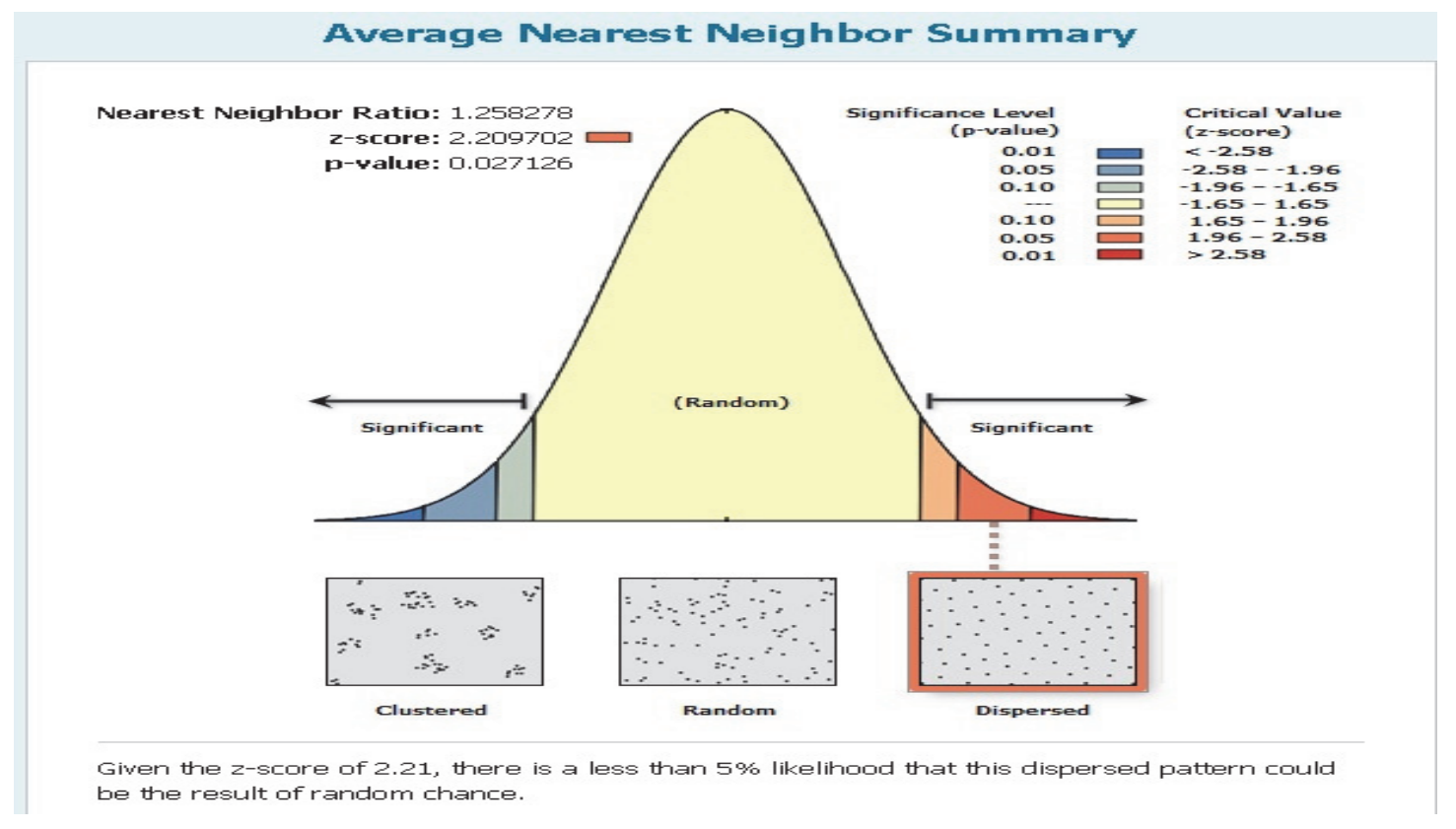

\begin{tabular}{|r|l|l|}
\hline \multicolumn{2}{|c|}{ Average Nearest Neighbor Summary } \\
\hline Observed Mean Distance: & 79.892167 \\
\hline Expected Mean Distance: & 63.493241 \\
\hline Nearest Neighbor Ratio: & 1.258278 \\
\hline z-score: & 2.209702 \\
\hline p-value: & 0.027126 \\
\hline Dataset Information \\
\hline Input Feature Class: & Link \\
\hline Distance Method: & EUCLIDEAN \\
\hline Study Area: & 322511.332421 \\
\hline
\end{tabular}

Figure 3. The output average nearest neighbor

Figure (3) shown the average nearest neighbor the values of the neighborhood link are equal to 2.15

The development strategy for a city is built on a density indicator for the roads network and the total length for all of them and their condition, this is considered a standard indicating economy development and prosperity. Furthermore, it's one of the quantum methods to assess the service provided by the road

There is a strong connection between the completion of the infrastructure for a country and its roads density, 
since roads is considered the most important element of the infrastructure of any country, where as the relationship is positive between the infrastructure completion percentage and the roads density in any given place. Having a dense roads network in an area is considered clear evidence on the availability of other services like clear water network and sewage network.

\subsection{Urban Land Use Patterns}

Land uses in Al Salt city were classified in to different types, these are Residential, agricultural, special residential, government, industrial, handicraft, countryside residence, commercial and green residential. Distribution of land use pattern in Al Salt city is unique in their mixture and combinations. It includes a mixture of residential, commercial and industrial. Beside the increase in the density of uses in general and commercial use in particularly in the city center. This indicates the weak planning and organizing of the land uses to populations needs, growth and their economic activities. Analyzing the population change patterns and urban growth for Al Salt show that the city center- old Salt- wasn't planned and grew randomly. Buildings are small and there is no space between the building and the other. Streets sizes are different and have many directions, and we can notice many narrow and sub roads like Al Hammam Street and Al Maydan Street.

Table 3 show the percentage distribution of each land use type in Al-Salt city. This indicate that the commercial and industrial land size is less than $6 \%$ of the total size, that's why the organizers must pay more attention to such land use type and provide more spaces and more appropriate locations to this category, since it's the main drivers of the economy and a main element in urban planning. The prosperity of a city is set according to its production of goods and services, and the presence of such business related land is vital just like the presence of an infrastructure.

Also focusing on more agricultural activities in the study area with a supporting commercial organization attracts more visitors and movers who would like to get away from the busy life style to a rural atmosphere. The study area location near the Amman can be beneficial and the land used in agriculture is relatively small although most of the land in the study area is fertile and considered fit for growing plant, especially with the presence of Mediterranean climate. This is due to the expansion of residential land on the expense of agricultural land and there is an obvious shortage of open spaces and public parks with $0.37 \%$ of the total land size and lack of places with agricultural activities. Although the economy in the Balqa governorate is mainly governed by agricultural activities and the area is near big markets and Residential areas within the study area, there are no parks with $99.35 \%$ of the land area, $81.15 \%$ has no gardens, and $54.63 \%$ of the land has no designated areas in the organization for public parks. This is because land designated for gardens and parks is not fully used and some of it is used for different purposes, which is a clear violation. Finally, it is obvious that residential use is the dominant one in Al Salt when compared to other land use types, and covers $77.19 \%$ of the total size of the city. This is a normal outcome due to the growing number of population recently in the last two decades.

Table 3. The Size of main land uses types in Al Salt city for the year 2015.

\begin{tabular}{lll}
\hline Land use pattern & Land use area (KM2) & Percentage (\%) \\
\hline Commercial & 0.59 & 1.66 \\
\hline Residential & 27.4 & 77.19 \\
\hline Agricultural & 1.38 & 3.88 \\
\hline Industrial & 0.48 & 1.35 \\
\hline Services & 0.87 & 2.45 \\
\hline Roads & 4.776 & 13.45 \\
\hline Total & 35.496 & 100 \\
\hline
\end{tabular}

Table 4 show the residential organization use pattern in Al Salt city for the year 2015. It shows that the residential purposes are dominant in $\mathrm{Al} \mathrm{Salt}$ city with focus on the large pieces of land that can be difficult to buy and the land isn't used effectively resulting from the lack of flexibility when it comes to specific residential conditions like resident's class A in not being able to use small pieces of land and different building methods and Residential class A is $39.96 \%$ from the total residential area, which is more than half in Al Salt city. This current percent is much higher than the optimal rate of residential use which is $57 \%$ form the space used in the city. 
Table 4. The Residential Land Use class according to the organization

\begin{tabular}{lll}
\hline Residential land use class & Area $(\mathrm{km} 2)$ & Percent $\%$ \\
\hline Residential A & 10.95 & $39.96 \%$ \\
\hline Residential A with special provisions & 3.043 & $0.01 \%$ \\
& & \\
\hline Residential B & 2.45 & $8.94 \%$ \\
\hline Residential C & 2.35 & $8.58 \%$ \\
\hline Residential C with special provisions & 0.7208 & $0.03 \%$ \\
\hline Special residential & 1.9 & $6.93 \%$ \\
\hline Special residential with special provisions & 0.2909 & $1.06 \%$ \\
\hline Residential D & 0.55 & $2.01 \%$ \\
\hline Residential country side & 0.35 & $1.28 \%$ \\
\hline Residential H & 0.59 & $2.15 \%$ \\
\hline Residential Green & 1.38 & $5.04 \%$ \\
\hline Residential Green with special provisions & 6.580 & $24.02 \%$ \\
\hline Total & 27.40 & $100 \%$ \\
\hline
\end{tabular}

Table 5 show that the industrial use in the study area is located in general between small and medium size. The spatial distribution of the industrial use show that there are crafts shops areas like the one in Al Bohaira sub-districts, also there are several industries established in the city center between residential neighborhoods like Wadi Al Reeh and Al Maydan areas. However, due to the weak organizational planning and high population growth; the area vicinity become too dense with residents were it shouldn't be, since it's a cause of disturbance to residents and causes mismanagement of land use pattern in the city. Also, a mixing patterns between the services uses and industrial uses in Al Salt city can be seen, this is resulted from the confusion in organizing cities, villages and buildings Law. Since there is no clear definition of industrial uses and there isn't any legal obligation to bind these uses, therefore the commercial sector in Al Salt city is growing fast especially along King Abdullah the Second Street, which puts some pressure on the development organization process. In addition, the difficulties to get into the commercial area because it's far from the residential areas which force the people to transfer to the city center all the time. Also, Al Salt city has no hierarchy in distributing commercial centers which creates traffic jams and chaos downtown.

Table 5 show the minimum size required for sorting the residential land use in 2015 year. It shows that the industrial use in the study area is located in general between small and medium. The minimum size of land class A that can be sorted is $1000 \mathrm{~m} 2$ and the length of its front should be more than $25 \mathrm{~m}$. This is considered a lack of futuristic view and for the city needs and unjustified waste of residential land and Residential areas class $\mathrm{H}$ was found to preserve the historical fabric of the City of Al Salt and it doesn't really match the actual size of the residential pieces of land since it was built before the regulation.

Table 5. The minimum size required for sorting the residential land use (land organize, 2015)

\begin{tabular}{llll}
\hline Type of organizing & $\begin{array}{l}\text { Minimum size } \\
\text { for sorting } \\
\text { land }(\mathrm{m} 2)\end{array}$ & $\begin{array}{l}\text { Front side length } \\
(\mathrm{m})\end{array}$ & $\begin{array}{l}\text { Construction } \\
\text { percentage } \\
(\%)\end{array}$ \\
\hline Agricultural residential & 4000 & 35 & 15 \\
\hline Green residential & 2000 & 30 & 15 \\
\hline Special residential & 1000 & 25 & 25 \\
\hline Residential class A & 1000 & 25 & 39 \\
\hline Residential class B & 750 & 20 & 45 \\
\hline Residential class C & 500 & 18 & 51 \\
\hline Residential class D & 250 & 15 & 55 \\
\hline Residential class H & 150 & 12 & 60 \\
\hline
\end{tabular}

We can notice from table (5) that every use has expanded on the expense of agricultural use. 


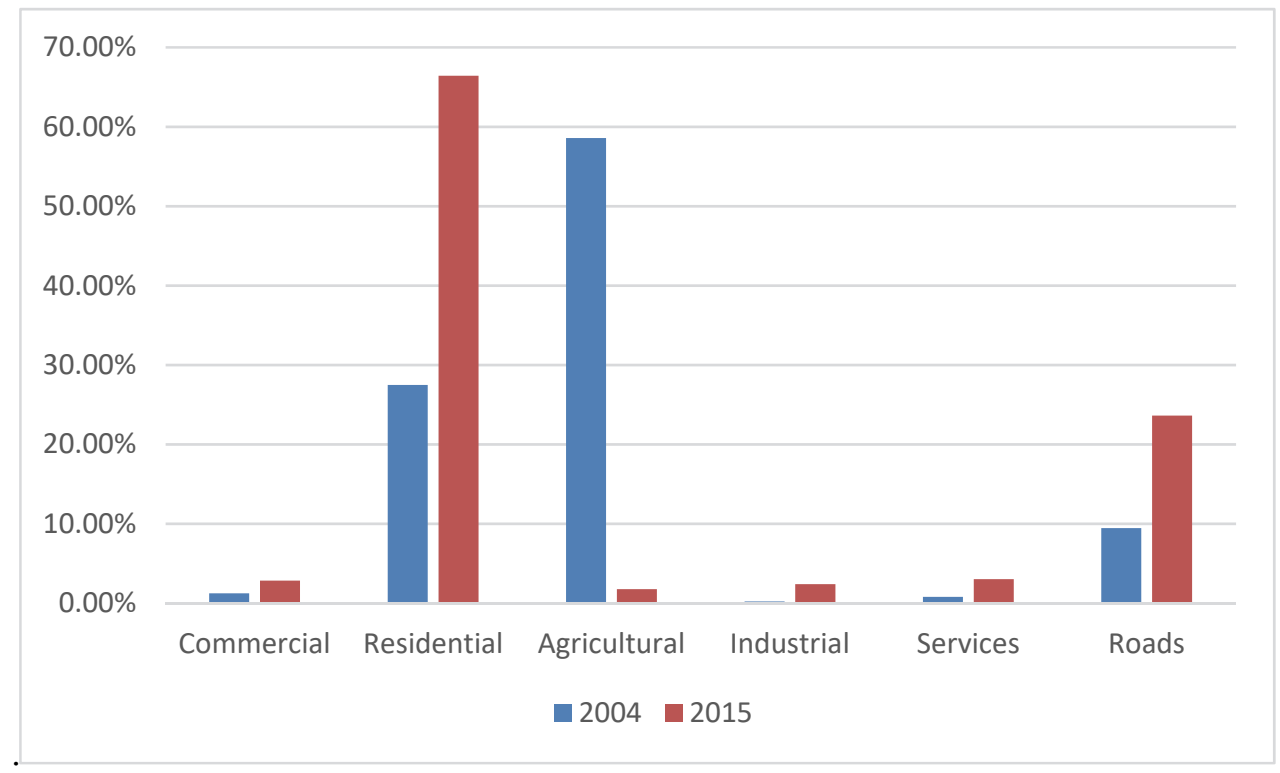

Figure 4. Comparison between land uses in Al Salt city during different period (2004-2015)

\subsection{Population Distribution in Al Salt City}

Residential areas are considered the main development regions in the urban management perspectives, the current residential patterns provide a descriptive view on the main developmental directions, infrastructure, market trends, housing demands and cultural impact on the location and qualities of development. The existing patterns can be used to help in the residential areas growth blueprints. The existing growth patterns represent the topographical nature of the area and the specific planning considerations. It has to do with filling empty spaces between the main residential areas, like the one that exists between Zay and Al Salt district area. The land organization law should be updated frequently to cope with the newest changes in the social, economic and structural land use, in some cases flexibility is required to deal with the empty spaces between the residential areas in order to limit the outward expansion. (Greater Al Salt Municipality,2016)

Figure 5 shows that the city of Salt witnessed significant population changes in the time period between 1952 1nd 2015 due to the high population growth rate. This rapid increase resulted in an unplanned urban expansion accompanied by an increase in the demand for land use for housing and public services, which led to appearing of mixed uses of land such as mixed residential, commercial and industrial uses. This was accompanied by problems such as high land prices, high density of population and traffic congestion, as well as increased demand for housing and services. (Greater Al Salt Municipality,2016) 


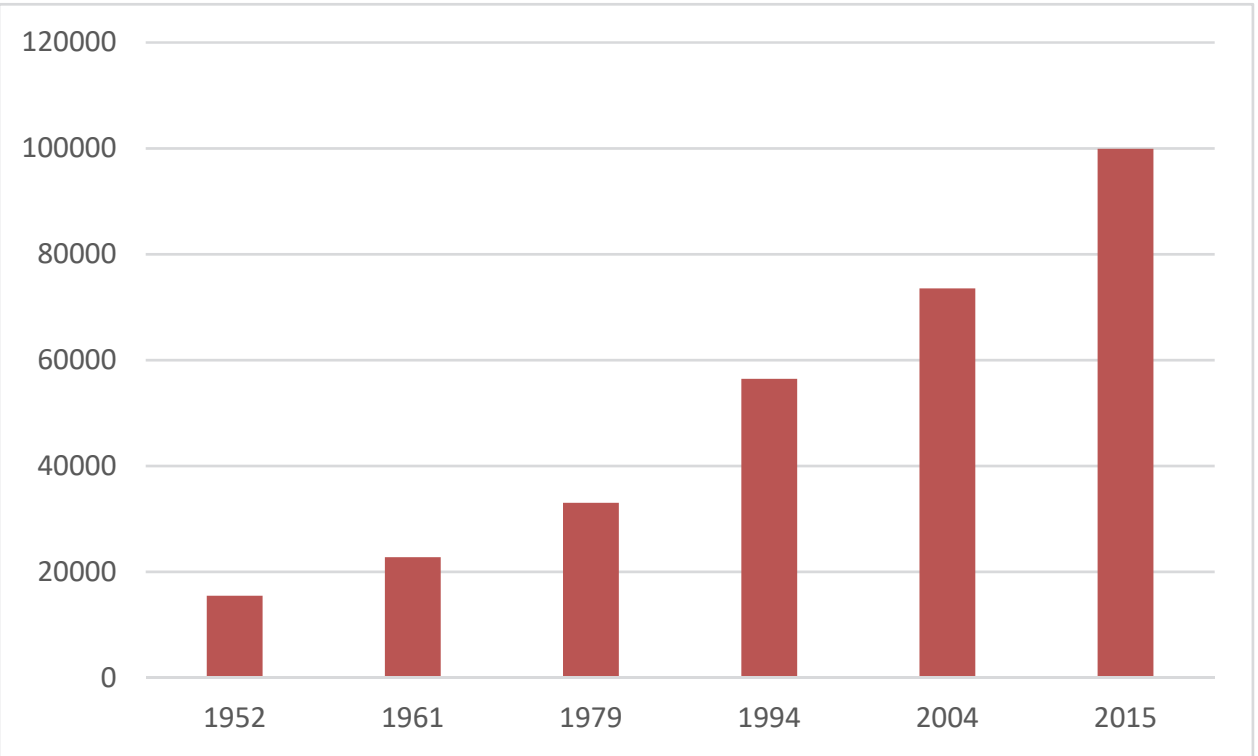

Figure 5. Population Growth in Al-Salt city

The result of population and residences survey showed that the growth rate in Al Salt city is $4 \%$ between 1944 and 1979, 2.6\% yearly between 1994 and 2004, and 2.4\% between the years 2004 to 2015 .

Both the natural increase has caused the increase in the population increases from (15478 inhabitants) in the year 1952 , to (56458 inhabitants) in the year 1994, to (73528 inhabitants) in the year 2004, to (88865 inhabitants) in the year 2011 to (99938 inhabitants) in the year 2015. Accordingly, the city size also expanded to cope the increase in population number, it was $3.200 \mathrm{Km} 2$ in the year 1952 and $35.993 \mathrm{Km} 2$ in the year 1994 and reached $48 \mathrm{Km} 2$ in the year 2015.

Accordingly, the built area size has increased in the Al-salt city, it was $2200 \mathrm{Km} 2$ in the year 1952 and increased to $7985 \mathrm{Km} 2$ in the year 1994, with an increase rate of $148 \mathrm{Km} 2$ yearly. The residential buildings number has also increased from 1730 in the year 1952 to 12317 in the year 1994, with an annual raise of 252 building. The department of Statistics expectations indicate that the demands on residential units in Al Salt city will increase from 20699 in 2010 to reach 32.631 residential units by the 2030 year with a $57.6 \%$ increase as shown in table 6 . (Land and Survey Department,2015)

Table 6. Predications the number of residential units in Al Salt city till 2030.

\begin{tabular}{|c|c|c|c|c|}
\hline City & $\begin{array}{l}\text { Number of } \\
\text { residential units } \\
\text { for the year } 2010\end{array}$ & $\begin{array}{l}\text { Number of } \\
\text { residential units } \\
\text { for the year } \\
2020\end{array}$ & $\begin{array}{l}\text { Number of } \\
\text { residential units } \\
\text { for the year } \\
2030\end{array}$ & $\begin{array}{c}\text { Change } \\
\text { percentage } \\
\text { between } \\
2010-2040\end{array}$ \\
\hline Al Salt & 20.699 & 26.474 & 32.631 & $57.6 \%$ \\
\hline
\end{tabular}

The population of Al Salt city according to 2011 estimate was 88865 inhabitants, living in $\mathbf{2 0}$ neighborhoods, and table 6 and figure 5 shows the difference of population distribution in different neighborhoods; Al Salalem neighborhood came first with 19912 inhabitants, this is because it's big size and the availability of basic services. Al Qassam neighborhood at the south west of the city came last since it is still new and suffer from the lack of services.

Table 7 and figure 6 show the population in Al-Salt city sub-districts. There are 20 sub-district, where the neighborhood of the Salalem occupies the largest area followed by the neighborhood of Al-Saafih and Bekaa while the district of the castle the smallest area, knowing that it is one of the oldest neighborhoods because of the presence of the old fortress of Turks. Population densities vary among the neighborhoods of Salt City, the highest value reaches in the neighborhood of stairs, which amounted to 23302 inhabitants, while the lowest value in the 
neighborhood of Kfarhuda. The largest population was in the area of Salalem in the year 2015 where it was 23302 inhabitants and then the neighborhood of the Safeh and the Bekaa 17309 inhabitants. In contrast, the district of Kfarhuda was the lowest population of 390 inhabitants and then the district of Batna 747 inhabitants and also note that there is migration For example, the area of Manshiyya in 2004 was 1810 inhabitants and became 1589 people in 2015 and also the region of Batna was 991 inhabitants in 2004 and became 747 inhabitants in 2015. Regarding the population density, it was found that the Jadaa sub-districts is the most densely populated neighborhood with 20.08 followed by the Qalaa by 1901, while Batna neighborhood has the lowest population densities with 0.13 I followed by Kfarhuda neighborhood by 0.17 .

Table 7. Population in Al-salt City sub-districts in 2015.

\begin{tabular}{|c|c|c|c|c|c|}
\hline $\begin{array}{l}\text { The name of the } \\
\text { neighborhood }\end{array}$ & $\begin{array}{l}\text { Population } \\
2015\end{array}$ & $\begin{array}{l}\text { Population } \\
2004\end{array}$ & $\begin{array}{l}\text { Area } \\
\mathrm{Km} 2\end{array}$ & $\begin{array}{l}\text { Population } \\
\text { density } \\
2015\end{array}$ & $\begin{array}{l}\text { Population } \\
\text { density } \\
2004\end{array}$ \\
\hline Kalaa & 6847 & 6042 & 360 & 19.01 & 16.78 \\
\hline Wade-halbee & 2581 & 2223 & 310 & 8.3 & 7.17 \\
\hline Al-Medan & 3022 & 1917 & 160 & 18.8 & 11.98 \\
\hline Al-Jadaa & 2611 & 2551 & 130 & 20.08 & 19.62 \\
\hline Al-Mansheeh & 1589 & 1810 & 330 & 4.72 & 5.48 \\
\hline AL-Aezreah & 2754 & 2358 & 250 & 11.016 & 9.43 \\
\hline Wadi Krad & 2086 & 2206 & 130 & 16.04 & 16.96 \\
\hline Al-Safeh and Baqeea & 17309 & 13217 & 4040 & 4.28 & 3.271 \\
\hline Sawaada & 8234 & 6412 & 4280 & 1.92 & 1.49 \\
\hline Kfarhuda & 390 & 481 & 2220 & 0.17 & 0.21 \\
\hline Al-Msalaa & 1118 & 635 & 1240 & 0.82 & 0.51 \\
\hline Al-Salalem & 23302 & 16475 & 5390 & 4.32 & 3.05 \\
\hline Alnaqeb & 6317 & 4149 & 2420 & 2.61 & 1.71 \\
\hline Alshafaa & 5578 & 3316 & 3160 & 1.76 & 1.04 \\
\hline Al-Serwo & 4063 & 1965 & 7400 & 0.54 & 0.26 \\
\hline Batnaa & 747 & 991 & 5360 & 0.13 & 0.18 \\
\hline Al-Qassam & 1033 & 254 & 2080 & 0.49 & 0.12 \\
\hline Aom Zitone & 2396 & 394 & 2880 & 0.83 & 0.13 \\
\hline Al-Miamen & 6588 & 5252 & 2620 & 2.51 & 2.00 \\
\hline Al-Mzawad & 1373 & 880 & 3580 & 0.38 & 0.24 \\
\hline Total & 99938 & 73528 & 48340 & & \\
\hline
\end{tabular}




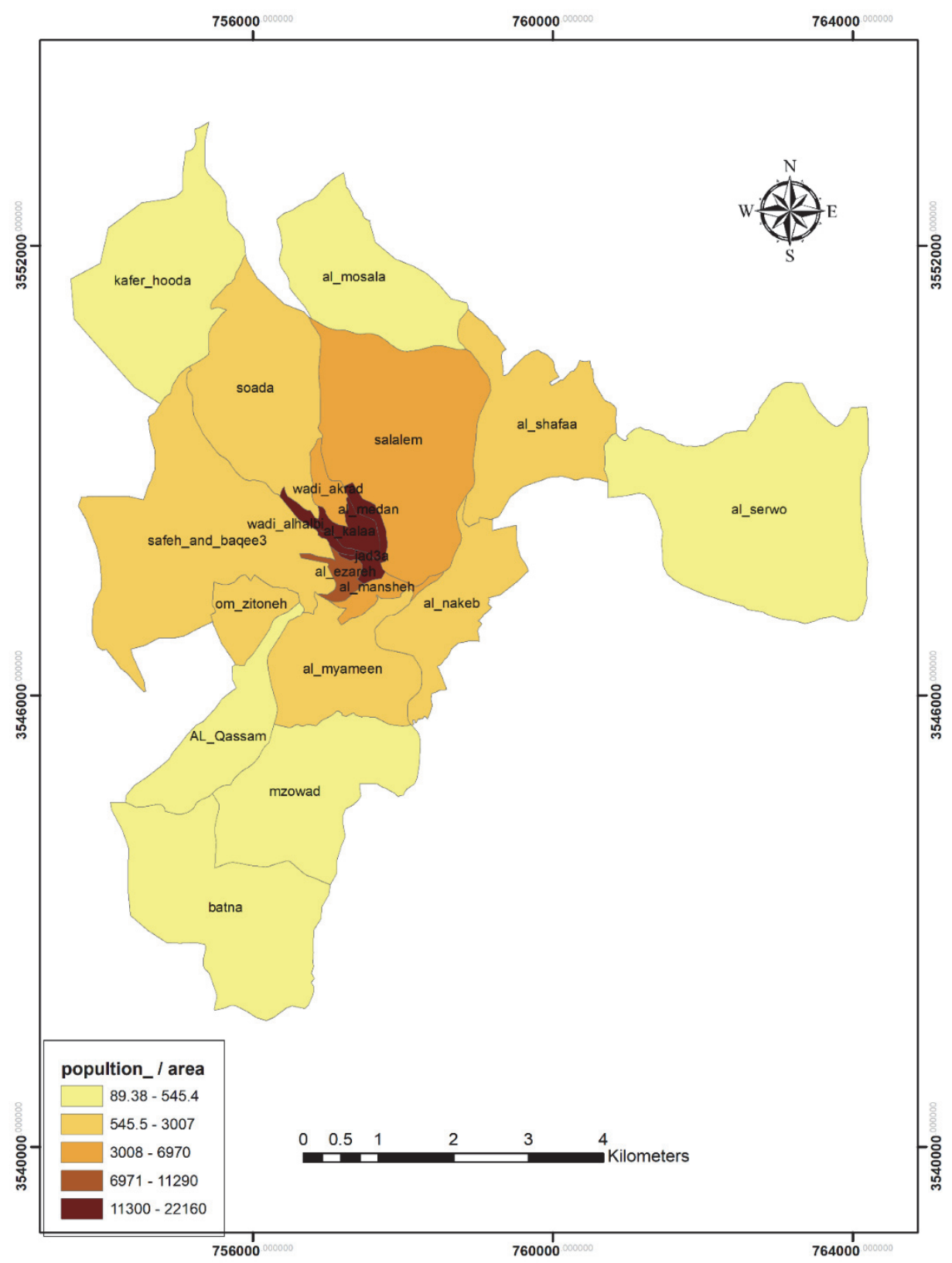

Figure 6. Density Population 2015

\section{Conclusions}

Analyzing land use pattern showed that the residential use is dominant in Al Salt city by far when compared with other uses; with $77.19 \%$ from the total area of the city. The land in the city is not used effectively due to the lack of flexibility and limited residential considerations for low density areas, such as residential classification A, for not being able to adopt smaller residential pieces of land and other building patterns. The Al Salt city witnessed important demographic changes and a significant increase in population. This resulted in an irregular expansion of settlements accompanied with high demand on residential land thus public services. This led to mixing the use of land for residential, commercial and industrial uses. All of this led to increased traffic jams and increasing the demand on housing and services dramatically. Urban management should intervene by setting out comprehensive national policy and enforcing more discipline on urban land uses patterns, and pass legislations 
to balance different land uses. This will preserve public interests and maintain the resources to future generation.

Al Salt city suffers from the limited size of usable land which gains even more importance as a natural source and foundation for living. The pressure on the usable land increases with the increase of the population and growth rates and the drop in the mortality rate; as a result of science advancement and improving health care. In addition to that, the increased pressure on the public places and services resulting from the population growth and the rapid advancement in human life and the change in the life styles and the priority of needs. All of this causes an increase on the demand of the land used for residential purpose, that's why we should organize and legalize the use of such land.

\section{References}

Abu Madena, H. (2008). Land roads network in Shoa'bat Marzooq. Al Satel magazine, 4, Libya.

Aduory, R. (2010). Geographical Analysis of the Network of Roads in the Duor for 2008, Journal of Tikrit University for the Humanities, 17(3).

Al Awaysheh, M. (2013). Population Change and its Impact on Land Use Patterns in Al Salt City from 1979 to 2010 By Using Geographical Information System, Jordan University, Jordan.

Al Jaberi, A \& Kamel A. (2010). The Use of Spatial Analysis Methodology in Assessing Spatial Fitness for Urban Expansion in Kuwait City. Faculty of Education magazine, 12.

Al Kanani, K \& Abdel.J. (2007). Determining of Interaction Levels in Urban Land Uses by Using Spatial Analysis Techniques. Development and Planning magazine, 6.

Al Khaldi, H. (2005). Assessing the Efficiency of Transportation network in Al Mahmoudayah District, Baghdad University, Iraq.

Al Sa'di, F. (2002). Population Geography, Dar Al kotob for printing and publishing, Baghdad.

Al Tarzy, A. (2003). Paved Roads Network in The Hashemite Kingdome of Jordan and its effect on Cities Growth, Al Yarmouk University. Jordan.

Ali, Zain A. (2001). Urban Transportation Planning Principles, Dar Al Safa for Publishing, Baghdad.

Arabiyat, M. (2012). Using Geomatics Technology in planning Cities an Applicable Study on Services and Health Care Facilities in Al Salt City, Al Balqa Applied University, Jordan.

Asdi, A. (2015). Study of Relationship Between Roads Network Development and Agricultural Land Conversion in Iran NorthWest. J. Environ, 10(1), 1735-6865

Chapin, F. (1995). Urban land Use Planning, University of Illinois, journal ELSEVER, 155-270.

Ghnaim, O. (1999). The Role of Topographical Element in Shaping and Directing Urban Development Patterns in Al Salt City, Jordan.

Ghnaim, O. (2004). Commercial Land Use and Traffic Accidents in Amman City, Damascus University magazine, Folder 20, 2, Syria.

Gorczyca, K., \& Koutula. L. (2006). Land Use Planning and Public Participation in Norway and Poland, Institute of Urban Development, Poland.

Greater Al Salt Municipality, Geographical information Systems Department, unpublished data. 2016.

Jie, Z., \&, Nguyen, X., \& Cheng, L. (2017). Investigation of the Impacts of Urban Land Use Patterns on Energy Consumption in China: A Case Study of 20 Provincial Capital Cities. Sustainability, 9, 1383.

Land and Survey Department. (2015). unpublished Data on the network of roads in the city of Salt, Jordan

Land Transport Regularity Commission, 2016.

Ministry of Municipal Affairs. (2005). Services Planning Standers Guide, Al Riyadh (1st ed).

Ministry of Public Works and Housing. (2016). unpublished Data on the network of roads in the city of Salt, Jordan.

OECD. 2017. The Governance of Land Use

Rahayu, A. (2015). Land use development and its impact on airport access road. Journal ELSEVER, 31-37.

Reisi, L. (2016). Land-use planning: Implications for transport sustainability, journal ELSEVER, 252-261.

Sarkar, D. (2013). Structural Analysis of Existing Road Networks of Cooch Behar District, West Bengal, India, 
Ethiopian. Journal of Environmental Studies and Management, 6(10). 74-81.

Shabat, A. (2011). The Road Transport Network in Gaza City (study on transport geography using GIS, (M. Sc. dissertation, Islamic University of Gaza. Palestine.

Shehab, A., \& Alladin, M. (1990). Spatial Requirements for Planning the City, Ministry of Scientific Research and Higher Education, Baghdad.

Taran, A., \& Makhamreh, Z. (2015). Quantitative Analysis of Road Network in the Mafraq Governorate. the Dirasat journal (Humanities and social sciences), 42.

Todd L. (2017). Evaluating Transportation Land Use Impacts Considering the Impacts, Benefits and Costs of Different Land Use Development Patterns--Victoria Transport Policy Institute

Todd L. (2017). Land Use Impacts on Transport How Land Use Factors Affect Travel Behavior 18 July -Victoria Transport Policy Institute with Rowan Steele.

Tofic, A. (2015). Integrated Co-evolution Model of Land Use and Traffic Network Design. Netw Spat Econ, 16, 579-603

Wen, D., \& Huang, X., Zhang, L., \& Benediktsson, J. A. (2016). A Novel Automatic Change Detection Method for Urban, Victoria Transport Policy Institute

Xie, Y., \& Weng, Q. (2016). Detecting urban-scale dynamics of electricity consumption at Chinese cities using time-series DMSP-OLS (Defense Meteorological Satellite Program-Operational Linescan System) nighttime light imageries. Energy, 100, 177-189.

\section{Copyrights}

Copyright for this article is retained by the author(s), with first publication rights granted to the journal.

This is an open-access article distributed under the terms and conditions of the Creative Commons Attribution license (http://creativecommons.org/licenses/by/4.0/). 